\title{
Measurement of oxytocin concentrations in plasma and ovarian extracts during the oestrous cycle of mares
}

\author{
K. R. Stevenson ${ }^{1}$, T. J. Parkinson ${ }^{2}$ and D. C. Wathes ${ }^{1 *}$ \\ ${ }^{1}$ Department of Anatomy, School of Medical Sciences, Bristol BS8 ITD, UK, and ${ }^{2}$ Department of \\ Veterinary Medicine, University of Bristol, Langford, Bristol BS18 7DU, UK
}

\begin{abstract}
Summary. Jugular venous blood samples were collected throughout a complete oestrous cycle from 9 mares for measurement of progesterone and oxytocin by radioimmunoassay. Mean oxytocin concentrations remained at $\sim 1 \mathrm{pg} / \mathrm{ml}$ throughout, with no evidence of cyclic variation in the release pattern. Extracts of corpus luteum and follicles obtained from a further 33 mares at different stages of the cycle all contained oxytocin concentrations of $<10 \mathrm{pg} / \mathrm{g}$ wet weight of tissue. We conclude that the ovaries are not a source of circulating oxytocin during the oestrous cycle in this species. The plasma oxytocin concentrations reported here are substantially lower than those found by other groups.
\end{abstract}

Keywords: oxytocin; mare; oestrous cycle

\section{Introduction}

Previous publications on the plasma concentration of oxytocin in mares have produced contradictory results. Burns et al. (1981) reported that concentrations were higher at oestrus and early dioestrus than in the mid and late luteal phases, whereas Tetzke et al. (1987) found greatest concentrations in the late luteal phase. A possible role for oxytocin in the control of luteolysis in this species was suggested by Goff et al. (1987), who found that the release of prostaglandin F-2 $\alpha$ (PGF-2 $\alpha$ ) in response to an oxytocin challenge varied during the cycle, the greatest response being achieved during luteolysis. However, oxytocin injections in either the early or midluteal phases did not affect the time of return to oestrus (Neely et al., 1979; Goff et al., 1987). The present study determined plasma oxytocin concentrations in cyclic mares using a well-defined radioimmunoassay (RIA), and investigated whether the equine ovary is a source of oxytocin as it is in domestic ruminants.

\section{Materials and Methods}

\section{Sample collection}

Jugular venous blood samples were collected daily from 9 Thoroughbred mares into $10-\mathrm{ml}$ heparinized vacutainers from 19 June to 17 July 1990 , inclusive. The blood was kept on ice and centrifuged at $1000 \mathrm{~g}$ within $15-30 \mathrm{~min}$ of collection. The plasma was divided into two aliquants, $1 \mathrm{ml}$ for progesterone $\mathrm{RIA}$ and the remainder $(\sim 4 \mathrm{ml})$ for oxytocin measurement. The plasma samples were frozen immediately on solid $\mathrm{CO}_{2}$. Progesterone samples were stored at $-20^{\circ} \mathrm{C}$ and assayed weekly. Oxytocin samples were stored at $-80^{\circ} \mathrm{C}$ and extracted within 1 week of collection.

\section{Radioimmunoassays}

Progesterone. Measurements were performed on $0 \cdot 1-\mathrm{ml}$ aliquants of plasma using petroleum ether extraction as described previously (Wathes et al., 1986). The detection limit was $22 \mathrm{pg} /$ tube, the extraction efficiency was $75 \pm 7.5 \%$, and the inter- and intra-assay coefficients of variation were 14.1 and $6.4 \%$, respectively.

*Present address and for reprint requests: AFRC Institute of Physiology and Genetics Research, Babraham, Cambridge CB2 4AT, UK. 
Oxytocin. Oxytocin was measured after extraction of 4-ml plasma samples on C1 8 cartridges (Jones Chromatography Ltd, Hengoed, Mid Glamorgan, UK) with minor modifications to a method described by Wathes et al. (1986). Columns were prewetted with $3 \mathrm{ml} 80 \%$ acetonitrile $\left(\mathrm{ACN}\right.$ ) in $0 \cdot 1 \%$ trifluoroacetic acid (TFA) followed by $5 \mathrm{ml} \mathrm{H}_{2} \mathrm{O}$. Plasma samples were prepared by dilution in an equal volume of phosphate buffer $\left(1.4 \mathrm{~g} \mathrm{Na}_{2} \mathrm{HPO}_{4} .2 \mathrm{H}_{2} \mathrm{O}, 0.26 \mathrm{~g}\right.$ $\left.\mathrm{KH}_{2} \mathrm{PO}_{4}, 8.65 \mathrm{~g} \mathrm{NaCl} / 1\right)$ and centrifugation for $10 \mathrm{~min}$ at $4^{\circ} \mathrm{C}$ and $1500 \mathrm{~g}$. They were then applied slowly to the columns and washed through with $20 \mathrm{ml} 10 \% \mathrm{ACN}$ in $0.1 \%$ TFA. Oxytocin was eluted with $3 \mathrm{ml} 80 \% \mathrm{ACN}$ in $0 \cdot 1 \%$ TFA. The ACN was removed by centrifugation in a rotary film evaporation centrifuge set at $35^{\circ} \mathrm{C}$ (Univap Uniscience, Cambridge, UK) and the remaining extract was freeze dried. The extract was redissolved in $0.5 \mathrm{ml}$ phosphate buffer containing $1 \mathrm{mg} / \mathrm{ml}$ bovine serum albumin (Sigma Chemical Co., Poole, Dorset, RIA grade). Aliquants of $50 \mu \mathrm{l}$ of this solution were measured in an RIA for oxytocin using a well-characterized antiserum $85 / 2$ (Gilbert $e t$ al., 1991). Separation was achieved using $0 \cdot 15 \mathrm{ml}$ anti-rabbit precipitating antibody (UCB BioProducts, Belgium). The sensitivity of the assay was $0.25 \mathrm{pg} /$ tube and the inter- and intra-assay coefficients of variation were 10.8 and $8.5 \%$, respectively.

Validation of this assay for use in horses was achieved using addition of oxytocin to the plasma both in vitro and in vivo. For the in-vitro method, oxytocin standard was added to a pool of either assay buffer or mare plasma at low and high concentrations. Buffer samples were measured without extraction and buffer and plasma samples were also extracted and assayed in triplicate. Results (all in $\mathrm{pg} / \mathrm{ml}$ with recovery percentages in parentheses) were as follows: low buffer (unextracted) $15 \cdot 8$, low buffer (extracted) $15 \cdot 9(100 \%$ ), high buffer (unextracted) $41 \cdot 6$, high buffer (extracted) $39 \cdot 1(94 \%)$, plasma (no additions) $1 \cdot 1$, low plasma $16 \cdot 1(95 \%)$, high plasma $39.9(93 \%)$.

For the in-vivo experiment, 2 mares were fitted with jugular vein cannulae under local anaesthesia and injected with 1 unit synthetic oxytocin (Syntocinon: Sandoz Ltd, Basle, Switzerland) directly into the jugular vein. The cannulae were filled with heparinized saline. Blood samples $(10 \mathrm{ml})$ were collected through the cannulae at $-10,-5,0,1$, $2,5,10,20$ and $30 \mathrm{~min}$ relative to the time of the injection. This procedure was performed twice on each horse at an interval of $2 \mathrm{~h}$. Samples were treated as described above.

\section{Ovarian extraction}

Ovarian tissue samples were collected from 33 mares at the abattoir within 10 min of slaughter, snap frozen in liquid nitrogen and stored at $-80^{\circ} \mathrm{C}$. They were classified according to appearance at the time of collection into corpora haemorrhagica $(n=5)$, corpora lutea $(n=13)$, corpora albicantia $(n=5)$, follicular wall $(n=5)$ and follicular fluid $(n=10)$. Samples were partially thawed, weighed $(0 \cdot 7-1 \cdot 3 \mathrm{~g})$ and chopped into $5 \mathrm{ml}$ ice-cold extraction medium ( $15 \% \mathrm{v} / \mathrm{v}$ TFA, $5 \% \mathrm{v} / \mathrm{v}$ formic acid, $1 \% \mathrm{w} / \mathrm{v} \mathrm{NaCl}$ in $1 \mathrm{~mol} \mathrm{HCl} / 1)$. The tissue was homogenized and centrifuged at $20000 \mathrm{~g}$ for $30 \mathrm{~min}$ at $4^{\circ} \mathrm{C}$ and the resulting supernatant was applied to $\mathrm{C} 18$ columns as described above. Freeze-dried extracts were reconstituted in $0.5 \mathrm{ml}$ assay buffer and the oxytocin concentration was estimated at 2 dilutions (neat and 1:10) as described.

\section{Results}

All 9 mares were exhibiting regular oestrous cycles as judged by their plasma progesterone profiles (Fig. 1). However, the oxytocin concentrations measured were consistently low $(<0.6-4.0 \mathrm{pg} / \mathrm{ml})$, the majority $(68 \%)$ being at or below the detection limit of the assay (Fig. 1). All ovarian extracts contained negligible amounts of oxytocin. Of the 38 samples measured, 18 were at or below the detection limit of the assay ( $2 \mathrm{pg} / \mathrm{g}$ wet weight) and the remainder were all $<10 \mathrm{pg} / \mathrm{g}$. In contrast, there was a clear variation in the ovarian progesterone concentration measured at different stages of the cycle. Values (in $\mu \mathrm{g} / \mathrm{g}$ ) were 0.3 in follicle walls $(n=2), 12.6 \pm 1.2$ in corpora haemorrhagica $(n=4), 74 \cdot 7 \pm 14 \cdot 1$ in corpora lutea $(n=11)$ and 0.6 in a corpus albicans $(n=1)$. There was no apparent correlation of either blood or ovarian oxytocin concentrations with the stage of the cycle.

As these results differed from previous reports, 2 further experiments were undertaken to validate the assay and extraction procedure. Recovery of exogenous oxytocin added to mare plasma in vitro was $\sim 95 \%$ (see Materials and Methods). Injection of 1 unit of oxytocin to mares in vivo resulted in the expected increase in circulating concentrations (Fig. 2). Values peaked at $19.7 \pm 2.34 \mathrm{pg} / \mathrm{ml}$ at $1 \mathrm{~min}$ after injection and returned to basal values of $0.8 \mathrm{pg} / \mathrm{ml}$ within $30 \mathrm{~min}$. This maximum value is close to the estimated concentration of $48 \mathrm{pg} / \mathrm{ml}$ based on an even distribution of 1 unit of oxytocin $(1.68 \mu \mathrm{g})$ within a blood volume of $\sim 351$.

\section{Discussion}

These results indicate that the ovary of the mare is not a source of oxytocin, and that there is no major change in the circulating concentration of oxytocin during the oestrous cycle. In this respect, 


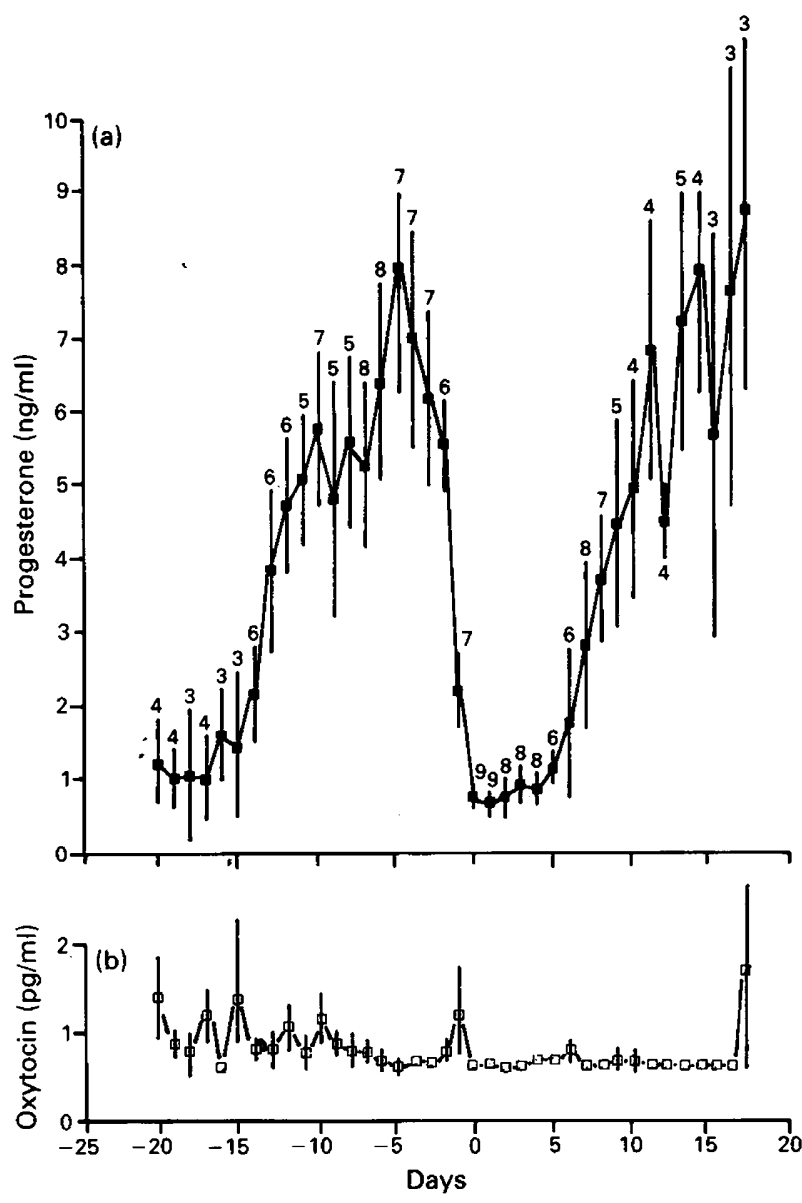

Fig. 1. Patterns of (a) progesterone ( $\square$ ) and (b) oxytocin ( $\square$ ) secretion measured in daily jugular venous samples collected from 9 mares. Values are centred around the day on which the plasma progesterone first dropped to $<2.5 \mathrm{ng} / \mathrm{ml}$ during luteolysis. The number of estimates is shown above each point. Concentrations are means \pm s.e.m.

horses clearly differ from domestic ruminants, in which there is substantial evidence that the corpus luteum synthesizes and secretes oxytocin during the cycle (Wathes \& Swann, 1982; Ivell \& Richter, 1984; Swann et al., 1984) and that this peptide is involved in the regulation of luteolysis (Flint \& Sheldrick, 1983).

Our results also differ from previous reports of oxytocin concentrations in mares' plasma (Burns et al., 1981; Tetzke et al., 1987). According to Burns et al. (1981), concentrations peaked at $\sim 80 \mathrm{pg} / \mathrm{ml}$ on Day 2 of oestrus and declined to $\sim 5 \mathrm{pg} / \mathrm{ml}$ on Day 10 . In direct contrast, Tetzke $e t$ al. (1987) found that concentrations were highest on Day 15 of the cycle with a mean of $170 \mathrm{pg} / \mathrm{ml}$ and lowest at oestrus $(83 \mathrm{pg} / \mathrm{ml})$. In both these reports concentrations were therefore at least one order of magnitude higher than those reported here. The most obvious difference in methodology relates to the assay procedure, as Burns $e t$ al. used unextracted plasma, whereas Tetzke et al. (1987) employed an acetone- $\mathrm{HCl}$ extraction procedure with Fuller's earth. It is possible that these procedures produced high levels of nonspecific binding; or the differences could relate to the different antisera used. The present paper also employed a lower sampling frequency than Tetzke et al. 


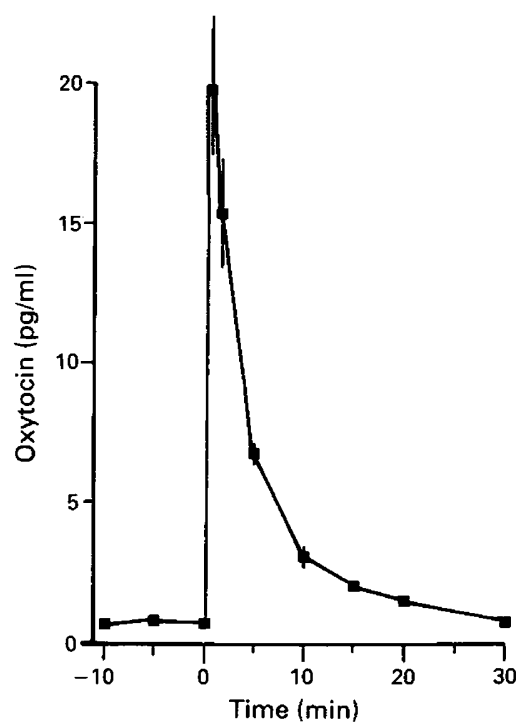

Fig. 2. Concentrations of oxytocin measured in jugular venous blood following the injection of mares with 1 unit of Syntocinon i.v. at time zero. Concentrations are means \pm s.e.m. of 4 samples at each point.

(1987). Whilst daily samples are clearly inadequate to characterize a pulsatile release pattern, previous work in ewes has demonstrated that this is sufficient to pick up cyclic variations of oxytocin release from the corpus luteum (Wathes et al., 1991).

Although the present results indicate that ovarian oxytocin is not involved in regulating reproductive tract activity in horses, this does not rule out the possibility that oxytocin of pituitary origin could play a role during the oestrous cycle. Goff et al. (1987) found that injections of large doses of oxytocin ( $10 \mathrm{iu} / \mathrm{kg}$ body weight) on various days of the cycle caused an increase in plasma 15-keto13,14-dihydro PGF-2 $\alpha$, with a maximum response on Day 16 of the cycle and a reduced response in pregnant vs. nonpregnant mares. As oxytocin release during luteolysis in ewes is pulsatile (Flint \& Sheldrick, 1983; Hooper et al., 1986) a similar pattern could have been missed by the once a day sampling protocol employed here. We have also reported a possible role for very short (1-4 min) oxytocin pulses in regulating motility of the ovine reproductive tract at oestrus (Gilbert et al., 1991). Evidence for a similar function for oxytocin in mares could best be provided by measurements of oxytocin receptors in the reproductive tract during the cycle.

We thank Professor A. E. Goodship and the Janssen Research Foundation for allowing use of their mares, J. Allen for excellent care of the animals, M. L. Wild for skilled technical assistance, the Journals of Reproduction and Fertility Ltd for provision of a vacation scholarship for K. R. Stevenson and and the Wellcome Trust for financial support.

\section{References}

Burns, P.J., Kumaresan, P. \& Douglas, R.H. (1981) Plasma oxytocin concentrations in cyclic mares and sexually aroused stallions. Theriogenology 16, 531-539.

Flint, A.P.F. \& Sheldrick, E.L. (1983) Evidence for a systemic role for ovarian oxytocin in luteal regression in sheep. J. Reprod. Fert. 67, 215-225.
Gilbert, C.L., Jenkins, K. \& Wathes, D.C. (1991) Pulsatile release of oxytocin into the circulation of the ewe during oestrus and mating and the early luteal phase. J. Reprod. Fert. 91, 337-346.

Goff, A.K., Pontbriand, D. \& Sirois, J. (1987) Oxytocin stimulation of plasma 15-keto-13,14-dihydro prostaglandin F-2 $\alpha$ during the oestrous cycle and early 
pregnancy in the mare. J. Reprod. Fert. Suppl. 35, $253-260$.

Hooper, S.B., Watkins, W.B. \& Thorburn, G.D. (1986) Oxytocin, oxytocin-associated neurophysin and prostaglandin F-2 $\alpha$ concentrations in the uteroovarian vein of pregnant and non-pregnant sheep. Endocrinology 119, 2590-2597.

Ivell, R. \& Richter, D. (1984) The gene for the hypothalamic hormone oxytocin is highly expressed in the bovine corpus luteum: biosynthesis, structure and sequence analysis. EMBO J. 3, 2351-2354.

Neely, D.P., Stabenfeldt, G.H. \& Sauter, C.L. (1979) The effect of exogenous oxytocin on luteal function in mares. J. Reprod. Fert. 55, 303-308.

Swann, R.W., O'Shaughnessy, P.J., Birkett, S.D., Wathes, D.C., Porter, D.G. \& Pickering, B.T. (1984) Biosynthesis of oxytocin in the corpus luteum. FEBS Lett. 174, 262-266.
Tetzke, T.A., Ismail, S., Mikuckis, G. \& Evans, J.W. (1987) Patterns of oxytocin secretion during the oestrous cycle of the mare. J. Reprod. Fert. Suppl. 35, $245-252$.

Wathes, D.C. \& Swann, R.W. (1982) Is oxytocin an ovarian hormone? Nature, Lond. 297, 225-227.

Wathes, D.C., Guldenaar S.E.F., Swann, R.W., Webb, R., Porter, D.G. \& Pickering, B.T. (1986) A combined radioimmunoassay and immunocytochemical study of ovarian oxytocin production during the periovulatory period of the ewe. J. Reprod. Fert. 78, 167-183.

Wathes, D.C., Ayad, V.J., Gilbert, C.L., McGof, S.A. \& Wathes, C.M. (1991) Influence of oxytocin infusion during oestrus and the early luteal phase on progesterone secretion and the establishment of pregnancy in ewes. J. Reprod. Fert. 92, 383-391.

Received 9 November 1990 